\title{
17-KETOSTEROID EXCRETION IN MEN WITH GOUT
}

\author{
BY \\ E. R. COOK, G. D. KERSLEY, AND M. LUSCOMBE \\ From the Rheumatism Research Unit, Royal National Hospital for Rheumatic Diseases, Bath
}

(RECEIVED FOR PUBLICATION APRIL 9, 1957)

The absence of clinical hypogonadism and repeated observations of a low 17-ketosteroid excretion in gout, led Wolfson, Guterman, Levine, Cohn, Hunt, and Rosenberg (1949) and Wolfson (1954) to suggest that in this disease the adrenal cortex produces an abnormal androgen, which is not metabolized to 17-ketosteroids.

Robinson, Conn, Block, Louis, and Katz (1949, 1952) also found a low ketosteroid excretion in gout, but Tarnopolsky, Montuori, and Schere (1950) and Butt and Marson (1952), using a polarographic technique, were unable to confirm these results. Recently Zacco and Perrini (1955) fractionated the urinary 17-ketosteroids from a small series of eight patients and five controls; they found that the gouty patients excreted a smaller quantity of total 17-ketosteroids, and their data suggests an alteration in the $\beta$-ketosteroid and androsterone proportions. The previously published data are summarized in Table I.

\section{Material and Methods}

In the present investigation we have studied the excretion of total and of individual ketosteroids by nineteen male gout patients and seventeen normal males. In four cases, examinations were carried out during attacks of gout before and during treatment with colchicine.

Every patient, at some time, had had typical attacks and raised plasma uric acid levels, and none had any gross renal dysfunction. In all cases the total 17ketosteroid excretion was estimated by two separate methods, and an aliquot of the total ketosteroid extract was then partitioned by chromatographic fractionation into eight parts.

For the purpose of comparing the mean values obtained, the 36 subjects were divided into two age groups:

(a) eight normal males and ten patients within the ages of 37-54 years;

(b) an older group comprising nine normal males and nine patients within the ages of 54-76 years.

TABLE I

EXCRETION OF NEUTRAL 17-KETOSTEROIDS BY GOUTY AND NORMAL MALES AS REPORTED BY VARIOUS WORKERS

\begin{tabular}{|c|c|c|c|c|c|c|c|c|}
\hline Pefer & nces & & & y Patients (M & les) & & ontrols (Male & \\
\hline Rerere & nees & & & & & & & \\
\hline Authors & & Date & Patients & (yrs) & (mg./24 hrs) & Controls & (yrs) & (mg./24 hrs) \\
\hline Wolfson and others & $\cdots$ & 1949 & 10 & 45 & $3 \cdot 2$ & $?$ & $?$ & $12 \cdot 9$ \\
\hline Robinson and others & $\cdots$ & 1949 & 10 & $?$ & Lower than norn & 1. No valu & iven (Abstrac & \\
\hline Tarnopolsky and othe & $\cdots$ & $1950^{*}$ & 7 & $?$ & $15 \cdot 7$ & $\begin{array}{l}\text { Compa } \\
\text { were no }\end{array}$ & $\begin{array}{l}\text { control gro } \\
\text { restigated }\end{array}$ & \\
\hline Butt and Marson & $\cdots$ & $1950 \dagger$ & 29 & 53 & $10 \cdot 1$ & in these & lies & \\
\hline Robinson and others & $\cdots$ & $1952 \ddagger$ & 13 & $?$ & $7-9$ & 7 & $?$ & $15-17$ \\
\hline Wolfson $\ldots$ & $\cdots$ & $1954 \S$ & 43 & $?$ & $8 \cdot 3$ & 26 & $?$ & $16 \cdot 0$ \\
\hline Zacco and Perrini & $\cdots$ & 1955 & 8 & $?$ & $2 \cdot 1$ & 5 & $?$ & $6 \cdot 5$ \\
\hline
\end{tabular}

* Calculated from author's data, omitting one patient with a very high value.

+ Calculated from author's data, omitting the results for four female gouty patients.

‡ Calculated from author's graph, containing 25 determinations from seven normal subjects and 34 determ inations from thirteen patients.

$\$$ Calculated from author's graph, assuming that each value represented one subject. 
Individual total 17 -ketosteroid and creatinine values for each patient were usually the mean of two or more separate 24-hr specimens; all values from doubtful specimens, judged on the basis of creatinine and volume, were discarded.

Patients whose urines contained more than traces of protein were not included in this survey, since it has been shown by Beher and Gaebler (1951) that the 17ketosteroids are not completely extracted from urines so contaminated. The ordinary tests for urinary protein were negative in seventeen of the patients, and barely positive in the remaining two.

As the constancy of the ketosteroid chromatographic pattern has been established for the normal male (e.g. Dobriner, 1953; Cook, Stitch, Hall, and Feldman, 1954; Johnsen, 1956a), only single 24 -hr urine specimens were collected from each normal control. A similar constancy for the gouty patient between attacks was established during this work, and consequently in twelve patients only single $24-\mathrm{hr}$ urine extracts were fractionated, the other individual mean figures being the average of at least two separate specimens.

The analytical methods employed are given in the Appendix.

\section{Results}

Table II shows that we could find no significant difference in the mean values for creatinine and total 17-ketosteroids (estimated by two methods) between the controls and gouty patients in comparable age groups; the Table shows the usual decrease of ketosteroid excretion with age.

Table III summarizes the average values of each subject obtained by the chromatographic technique, the various fractions being expressed as a percentage of the total 24-hr value. The Table shows a tendency for the patients in both age groups to excrete slightly lower proportions of Fractions III and IV, and slightly higher proportions of Fractions V, VI, VII, and VIII than the control. The difference is not significant except in Fraction $V$ (etiocholanolone) in the younger group $(P<0 \cdot 01)$. There is also a tendency for Fractions I and III to decrease with age in patients and controls, as previously shown for normal males by Johnsen (1956b).

TABLE II

EXCRETION OF CREATININE AND NEUTRAL 17-KETOSTEROIDS BY NORMAL AND GOUTY MALES

\begin{tabular}{|c|c|c|c|c|c|c|c|c|c|c|c|}
\hline \multirow{3}{*}{\multicolumn{2}{|c|}{ Group }} & & \multirow{3}{*}{$\begin{array}{c}\text { Number } \\
\text { of } \\
\text { Subjects }\end{array}$} & \multirow{2}{*}{\multicolumn{2}{|c|}{ Age (yrs) }} & \multirow{2}{*}{\multicolumn{2}{|c|}{ Creatinine (g./24 hrs) }} & \multicolumn{4}{|c|}{ 17-Ketosteroids (mg./24 hrs) } \\
\hline & & & & & & & & \multicolumn{2}{|c|}{ Method 1} & \multicolumn{2}{|c|}{ Method 2} \\
\hline & & & & Mean & Range & $\begin{array}{c}\text { Mean } \\
\text { (Range) }\end{array}$ & $\underset{\text { Error }}{\text { Standard }}$ & $\begin{array}{c}\text { Mean } \\
\text { (Range) }\end{array}$ & $\underset{\text { Error }}{\text { Standard }}$ & $\begin{array}{c}\text { Mean } \\
\text { (Range) }\end{array}$ & $\begin{array}{c}\text { Standard } \\
\text { Error }\end{array}$ \\
\hline Controls & . & .. & 8 & $47 \cdot 8$ & $37-54$ & $\begin{array}{c}1 \cdot 58 \\
(0 \cdot 9-2 \cdot 05)\end{array}$ & $0 \cdot 11$ & $\begin{array}{c}15 \cdot 1 \\
(6 \cdot 6-23 \cdot 2)\end{array}$ & $2 \cdot 0$ & $\begin{array}{c}12 \cdot 6 \\
(5 \cdot 6-19 \cdot 7)\end{array}$ & $1 \cdot 8$ \\
\hline Gouty & .. & .. & 10 & $46 \cdot 2$ & $39-54$ & $\begin{array}{c}1 \cdot 74 \\
(1 \cdot 16-2 \cdot 0)\end{array}$ & 0.09 & $\begin{array}{c}13 \cdot 5 \\
(6 \cdot 9-18 \cdot 8)\end{array}$ & $1 \cdot 3$ & $\begin{array}{c}10 \cdot 6 \\
(5 \cdot 3-15 \cdot 8)\end{array}$ & $1 \cdot 1$ \\
\hline Controls & .. & & 9 & $61 \cdot 3$ & $56-76$ & $\begin{array}{c}1 \cdot 49 \\
(0 \cdot 8-2 \cdot 2)\end{array}$ & $0 \cdot 15$ & $\frac{8 \cdot 9}{(4 \cdot 1-16 \cdot 5)}$ & $1 \cdot 1$ & $\begin{array}{c}7 \cdot 1 \\
(3 \cdot 8-12 \cdot 4)\end{array}$ & $1 \cdot 1$ \\
\hline Gouty & . & & 9 & $62 \cdot 0$ & $54-73$ & $\begin{array}{c}1 \cdot 59 \\
(1 \cdot 28-1 \cdot 96)\end{array}$ & 0.09 & $(4 \cdot 6-12 \cdot 2)$ & 0.9 & $\begin{array}{c}7 \cdot 6 \\
(5 \cdot 3-13 \cdot 2)\end{array}$ & 0.8 \\
\hline
\end{tabular}

TABLE III

EXCRETION OF FRACTIONATED NEUTRAL 17-KETOSTEROIDS BY NORMAL AND GOUTY MALES

\begin{tabular}{|c|c|c|c|c|c|c|c|c|c|}
\hline \multirow[b]{2}{*}{ Group } & \multirow{2}{*}{$\begin{array}{l}\text { Number } \\
\text { of } \\
\text { Subjects }\end{array}$} & \multirow{2}{*}{$\begin{array}{c}\text { Mean } \\
\text { Age } \\
\text { (yrs) }\end{array}$} & \multicolumn{7}{|c|}{ Distribution of $17-$ Ketosteroids (each fraction calculated as $\%$ of total) } \\
\hline & & & $\underset{(\text { Range) }}{\text { I }}$ & $\underset{\text { (Range) }}{\text { III }}$ & 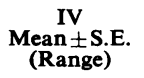 & 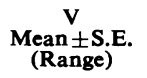 & $\underset{\substack{\text { Mean } \pm S . E . \\
\text { (Range) }}}{\text { VI }}$ & $\begin{array}{c}\text { VII } \\
\text { Mean }\end{array}$ & $\begin{array}{l}\text { VIII } \\
\text { Mean }\end{array}$ \\
\hline Controls & 8 & $47 \cdot 8$ & $\begin{array}{l}10 \cdot 0 \pm 1 \cdot 2 \\
(4 \cdot 7-16 \cdot 6)\end{array}$ & $\begin{array}{c}13 \cdot 9 \pm 2 \cdot 0 \\
(7 \cdot 7-22 \cdot 5)\end{array}$ & $\begin{array}{c}36 \cdot 9 \pm 1 \cdot 8 \\
(30 \cdot 2-44 \cdot 0)\end{array}$ & $\begin{array}{c}30 \cdot 4 \pm 1 \cdot 7 \\
(20 \cdot 9-38 \cdot 0)\end{array}$ & $\begin{array}{r}7 \cdot 7 \pm 0 \cdot 67 \\
(5 \cdot 2-11 \cdot 1)\end{array}$ & $0 \cdot 2$ & $0 \cdot 8$ \\
\hline Gouty & 10 & $46 \cdot 2$ & $\begin{array}{l}10 \cdot 4 \pm 1 \cdot 4 \\
(3 \cdot 9-17 \cdot 7)\end{array}$ & $\begin{array}{l}10 \cdot 2 \pm 1 \cdot 9 \\
(5 \cdot 5-25 \cdot 8)\end{array}$ & $\begin{array}{l}31 \cdot 6 \pm 2 \cdot 6 \\
(9 \cdot 1-39 \cdot 6)\end{array}$ & $\begin{array}{c}38 \cdot 1 \pm 1 \cdot 4 \\
(28 \cdot 9-43 \cdot 7)\end{array}$ & $\begin{array}{r}8 \cdot 3 \pm 0 \cdot 92 \\
(5 \cdot 1-14 \cdot 8)\end{array}$ & $0 \cdot 3$ & $1 \cdot 0$ \\
\hline Controls .. & 9 & $61 \cdot 3$ & $\begin{array}{c}6 \cdot 3 \pm 0 \cdot 47 \\
(4 \cdot 5-10 \cdot 3)\end{array}$ & $\begin{array}{l}10 \cdot 7 \pm 1 \cdot 2 \\
(4 \cdot 9-17 \cdot 0)\end{array}$ & $\begin{array}{c}40 \cdot 2 \pm 2 \cdot 9 \\
(25 \cdot 6-55 \cdot 0)\end{array}$ & $\begin{array}{c}33.9 \pm 2.9 \\
(19 \cdot 6-49 \cdot 5)\end{array}$ & $\begin{array}{c}7 \cdot 7 \pm 0 \cdot 83 \\
(4 \cdot 7-12 \cdot 4)\end{array}$ & $0 \cdot 4$ & $0 \cdot 7$ \\
\hline Gouty & 9 & $62 \cdot 0$ & $\begin{array}{l}6 \cdot 2 \pm 0 \cdot 47 \\
(3 \cdot 3-7 \cdot 5)\end{array}$ & $\begin{array}{r}8 \cdot 5 \pm 1 \cdot 4 \\
(3 \cdot 0-16 \cdot 2)\end{array}$ & $\begin{array}{c}35 \cdot 9 \pm 3 \cdot 0 \\
(18 \cdot 7-50 \cdot 0)\end{array}$ & $\begin{array}{c}39 \cdot 2 \pm 2 \cdot 8 \\
(28 \cdot 7-57 \cdot 0)\end{array}$ & $\begin{array}{l}8 \cdot 6 \pm 0 \cdot 3 \\
(5 \cdot 9-10 \cdot 7)\end{array}$ & $0 \cdot 5$ & $1 \cdot 1$ \\
\hline
\end{tabular}


In Table IV the mean values have been expressed as $\mathrm{mg}$. of each fraction excreted in $24 \mathrm{hrs;}$ Fractions I and III have been added together to give a more accurate estimate of the dehydroisoandrosterone or $\beta$-ketosteroid excretion (see Appendix).

No difference was found in the excretion of the respective fractions expressed as $\mathrm{mg}$. $/ 24 \mathrm{hrs}$ between patients and controls in the older group, but in the younger group the patients excreted $0.8 \mathrm{mg}$. $/ 24 \mathrm{hrs}$ dehydroisoandrosterone and $1.4 \mathrm{mg}$. $/ 24 \mathrm{hrs}$ androsterone less than the controls. These differences are not significant.

The variations between patients and controls being most pronounced in the younger group, it was considered possible that there might be a difference between patients in the early stages of the disease, and those with gout of long standing. The patients were therefore divided into two further groups:

(A) Nine men with a mean age of 50 years (range 39 to 62) who had had clinical gout for an average of 4 years (range 2 to 7 );

(B) Eight men with a mean age of 59 years (range 43 to 73) who had had the disease for an average of 25 years (range 13 to 46 ).

The mean values obtained, shown in Table $\mathrm{V}$, indicate that, whereas the total ketosteroid excretion diminished with age, the duration of disease had no obvious effect upon the steroid excretion pattern.

\section{Discussion}

Decreases in 17-ketosteroid excretion with age similar to those shown in our Table II are illustrated in comprehensive studies of normal subjects by Hamburger (1948), Sprechler (1951), and Johnsen (1956b). Previous evidence for a normal excretion in gout has been given by Tarnopolsky and others and by Butt and Marson. However, Wolfson (1954) has criticized the polarographic method employed by the latter authors, on the basis that "it is not a valid method of estimating 17-ketosteroid excretion as shown by its failure to show low values in gout patients". It is probable, however, that the technique is more specific than the many modifications of the colorimetric Zimmerman reaction (Barnett, Henly, and Morris, 1946). Barnett, Henly, Morris, and Warren (1946) and Butt, Morris, Robinson, and Warren (1951) have shown that in normal subjects the colorimetric method may give somewhat higher results than the polarographic technique. It is also of significance that, using the same urine hydrolysis and extraction technique as Butt and Marson (Appendix, Method 1), our mean 17-ketosteroid values, estimated colorimetrically,

TABLE IV

EXCRETION OF FRACTIONATED NEUTRAL 17-KETOSTEROIDS BY NORMAL AND GOUTY MALES

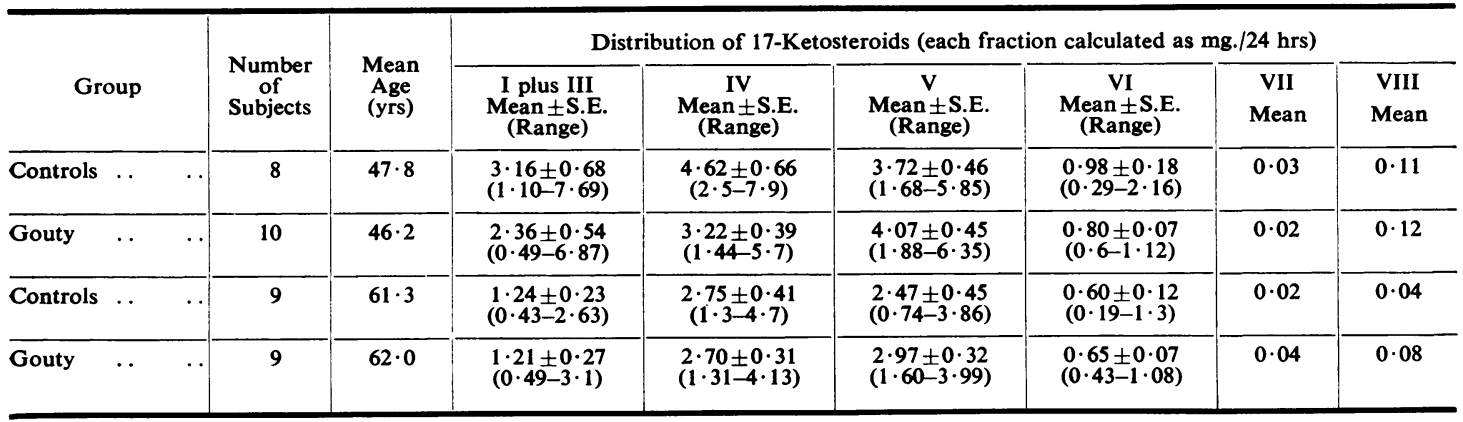

TABLE V

EXCRETION OF NEUTRAL 17-KETOSTEROIDS IN SHORT- AND LONG-TERM GOUTY PATIENTS

\begin{tabular}{|c|c|c|c|c|c|c|c|c|c|}
\hline \multirow{2}{*}{ Group } & \multirow{2}{*}{$\begin{array}{c}\text { Mean } \\
\text { Age } \\
\text { (yrs) }\end{array}$} & \multirow{2}{*}{$\begin{array}{c}\text { Mean } \\
\text { Duration } \\
\text { of Disease } \\
\text { (yrs) }\end{array}$} & \multirow{2}{*}{$\begin{array}{c}\text { Method } \\
\text { (see } \\
\text { Appendix) }\end{array}$} & \multirow{2}{*}{$\begin{array}{c}\text { Total } \\
\text { 17-Ketosteroids } \\
\text { (mg./24 hrs) }\end{array}$} & \multicolumn{5}{|c|}{ Fractions (per cent.) } \\
\hline & & & & & I & III & IV & $\mathbf{V}$ & VI \\
\hline $\mathbf{A}$ & 50 & 4 & $\begin{array}{l}1 \\
2\end{array}$ & $\begin{array}{l}12 \cdot 2 \\
10 \cdot 1\end{array}$ & $8 \cdot 1$ & $8 \cdot 8$ & $35 \cdot 8$ & $38 \cdot 1$ & $7 \cdot 8$ \\
\hline B & 59 & 25 & $\begin{array}{l}1 \\
2\end{array}$ & $\begin{array}{l}9 \cdot 6 \\
7.9\end{array}$ & $8 \cdot 1$ & $8 \cdot 5$ & $34 \cdot 2$ & $38 \cdot 8$ & $8 \cdot 7$ \\
\hline
\end{tabular}


were 13.5 and $8.4 \mathrm{mg} . / 24 \mathrm{hrs}$ for patients with mean ages of 46 and 62 respectively, compared with the polarographically determined ketosteroid value of $10 \mathrm{mg}$. $/ 24 \mathrm{hrs}$ for patients aged 53 obtained by Butt and Marson (Table I).

It may well be that the conflicting conclusions reached in previous investigations can be explained by inadequate control of the factor of age in group comparison, together with differing scales of values obtained by the various analytical methods. A contributory factor may be the suggested low 17-ketosteroid values resulting from the presence of protein in the urine of patients with renal complications.

Effect of Colchicine.-The 17-ketosteroid output of four of our patients was studied before and during an attack of gout treated with colchicine, but no significant or consistent changes were observed in either total steroid production or fractionation patterns. These findings confirm the previous work of Levine and Gregory (1951) and of Levine, Fred, and Bassett (1952), who have shown that therapeutic doses of colchicine have no effect upon the pituitaryadrenal axis of gouty patients or upon the 17ketosteroid excretion of non-gouty patients. Robinson and others (1952) also found that colchicine had no effect on 17-ketosteroid excretion in the gouty patient.

\section{Summary}

(1) Determinations of the total and fractionated urinary neutral 17-ketosteroids have been carried out on nineteen men with gout and seventeen controls.

(2) No significant differences in total 17-ketosteroid excretion were observed between patients and controls of comparable ages, although the usual changes with increasing age were seen.

(3) There was a tendency for the younger gouty patient to excrete slightly less $\beta$-ketosteroids and androsterone than the younger controls, resulting in a slightly lower total 17-ketosteroid output. This trend, which was not statistically significant, was not found in the older patients.

(4) The duration of the disease appeared to have no effect upon the steroid fractionation pattern.

(5) Acute attacks of gout treated with colchicine caused no significant variation in total ketosteroid excretion or in the fractionation pattern, although slight erratic changes were seen.

The authors are deeply indebted to Dr. M. R. Jeffrey for his help and advice, and to Mr. R. Hancock for technical assistance.

\section{REFERENCES}

Barnett, J., Henly, A. A., and Morris, C. J. O. R. (1946). Biochem. J., 40, 445 .

Behe, W, and Warren, F. L. (1946). Ibid., 40, 778.

. Anal. Chem., 23, 118.

. R. and Marson, F. G. W. (1952). Brit. med. J., 2, 1023. Morris, C. J. O. R., Robinson, A. M., and Warren, F. L. (1951). J. Endocr., 7, xii.

Callow, N. H., Callow, R. K., Emmens, C. W., and Stroud, S. W. (1939). Ibid., 1, 76

Cook, E. R., and Rooks, M. E. (1952). Analyst, 77, 525.

Stitch, S. R., Hall, A. E., and Feldman, M. P. (1954). Ibid., 79, 24.

Dingemanse, E., Huis in't Veld, L. G., and de Laat, B. M. (1946). J. clin. Endocr., 6, 535.

,-- and Hartogh-Katz, S. L. (1952). Ibid., 12, 66

Dobriner, K. (1953). J. clin. Invest., 32, 950.

Dorfman, R. I. (1954). "Recent Progress in Hormone Research", vol. 9, p. 5. Academic Press, New York.

Hamburger, C. (1948). Acta endocr. (Kbh.), 1, 19.

Johnsen, S. G. (1956a). Ibid., 21, 127.

- (1956b). Ibid., 21, 146.

Levin, M. H., Fred, L. and Bassett, S. H. (1952). J. clin. Endocr.,

Levine, H., and Gregory, R. (1951). J. Lab. clin. Med., 38, 921.

Lieberman, S., Mond, B., and Smyles, E. (1954). "Recent Progress in Hormone Research", vol. 9, p. 113. Academic Press, New York.

Palmer, D. B., and Rundle, A. T. (Private communication.)

Pond, M. H. (1951). Lancet, $2,906$.

Robinson, A. M. (1954). "Recent Progress in Hormone Research", vol. 9 , p. 163. Academic Press, New York.

Robinson, W. D., Conn, J. W., Block, W. D., Louis, L. H., and Katz, J. (1949). Annals of the Rheumatic Diseases, $8,312$.

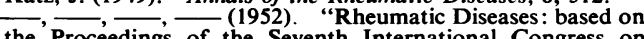
ings of the Seventh International Congress on Rheumatic Diseases" p. 241. Saunders, Philadelphia and

London
Sprechler, M. (1951). Acta endocr. (Kbh.), 7, 330.

Talbot, N. B., Berman, R. A., and MacLachlan, E. A. (1942). J. biol. Chem., 143, 21 i.

Tarnopolsky, S., Montuori, E., and Schere, M. (1950). Prensa med. Argent., 37, 1778.

Wolfson, W. Q. (1954). "Recent Progress in Hormone Research", vol. 9, p. 154. Academic Press, New York.

-, Guterman, H. S., Levine, R., Cohn, C., Hunt, H. D., and Rosenberg, E. F. (1949). J.' clin. Endocr., 9, 497.

Zacco, M., and Perrini, M. (1955). Reumatismo, 7, 138.

Excrétion des 17-cétostéroìdes chez les hommes goutteux

\section{RÉSUMÉ}

(1) On a déterminé les 17-cétostéroïdes urinaires neutres, totaux et fractionnés chez 19 goutteux et 17 témoins.

(2) On n'a observé aucune différence significative d'excrétion 17-cétostéroïde totale entre les malades et les témoins d'âge comparable, bien que les différences usuelles dues à l'âge fussent apparentes.

(3) Il existait une tendance chez les jeunes goutteux à excréter un peu moins de $\beta$-cétostéroïdes et d'androstérone que les jeunes témoins, donnant ainsi une excrétion 17-cétostéroïde totale un peu plus basse. Cette tendance, qui n'était pas statistiquement significative, n'a pas été constatée chez les malades plus âgés.

(4) La durée de la maladie ne semblait pas avoir d'effet sur le tableau des stéroïdes fractionnés.

(5) Les attaquës aigues de goutte, traitées à la colchicine, n'ont produit aucune variation significative dans l'excrétion cétostéroïde totale ou dans la disposition des fractions, bien que des légéres altérations erratiques fussent observées.

\section{Excreción de 17-cetoesteroides en hombres gotosos SUMARIo}

(1) Se determinaron los 17-cetoesteroides urinarios neutros, totales $\mathrm{y}$ fraccionados en 19 hombres gotosos y 17 testigos. 
(2) No se vió diferencia significativa alguna de excreción 17-cetoesteroide total entre los enfermos y los testigos de edad comparable, aunque diferencias habituales debidas a la edad fuesen aparentes.

(3) Hubo una tendencia en los gotosos más jóvenes a excretar algo menos de $\beta$-cetoesteroides y de androsterona que los jóvenes testigos, dando así una excreción 17-cetoesteroide total algo menor. Esta tendencia, que no fué significativa estadísticamente, no se reveló en los enfermos más viejos.

(4) La duración de la enfermedad no pareció afectar el cuadro de los esteroides fraccionados.

(5) Los ataques agudos de gota, tratados con colchicina, no produjeron variaciones significativas en la excreción cetoesteroide total o en la disposición de las fracciones, aunque se observasen pequeñas alteraciones erráticas.

\section{APPENDIX}

\section{Methods}

\section{TOTAL 17-KetosteroiDS}

Method 1.-100 ml. urine were hydrolysed and extracted by the method of Butt and Marson (1952). The washed extract was diluted to $150 \mathrm{ml}$. with benzene, and triplicate $10-\mathrm{ml}$. aliquots were evaporated to dryness for the Zimmerman reaction described by Cook, Stitch, Hall, and Feldman (1954). The values obtained were corrected for non-specific chromogenic material by the formula of Talbot, Berman, and MacLachlan (1942).

Method 2. $-200 \mathrm{ml}$. urine were removed from a 24-hr specimen for the estimation previously detailed, and the remainder hydrolysed and extracted by the procedure of Callow, Callow, Emmens, and Stroud (1939). The washed extract was adjusted to $50 \mathrm{ml}$., and triplicate $0.25-\mathrm{ml}$. aliquots were evaporated to dryness for estimation by the Zimmerman reaction. The non-specific material was corrected by a suitable factor obtained by the technique of Cook and Rooks (1952).

\section{Chromatographic Fractionation of the Total 17-KeTOSTEROID EXTRACT}

An aliquot containing 1.4 to $1.8 \mathrm{mg}$. ketosteroid was taken from the bulk urine extract of Method 2 and chromatographed by the method of Pond (1951), employing a slightly modified elution sequence devised by Palmer and Rundle (private communication). Perfect separation of the various peaks was regularly obtained, providing that the water content of the alumina was strictly controlled.
It seems probable (Dingemanse, Huis in't Veld, and de Laat, 1946; Dingemanse, Huis in't Veld, and Hartogh-Katz, 1952; Pond, 1951; Cook and others, 1954; Robinson, 1954; Johnsen, 1956a) that the fractions obtained by the chromatographic separation are:

(i) Hydrolytic artefacts of dehydroisoandrosterone;

(ii) i-androstan-6-ol-17-one, not seen in acid hydrolysed urines;

(iii) The $\beta$-ketosteroids, dehydroisoandrosterone and isoandrosterone;

(iv) Androsterone, and the $\triangle 9: 11$ derivative;

(v) Etiocholanolone, and the $\triangle 9: 11$ derivative;

(vi) 11-hydroxy and 11-ketoandrosterone;

(vii) 11-hydroxyetiocholanolone;

(viii) Unidentified, but present in very small amounts.

The cyclic steroid i-androstan-6-ol-17-one is a hydrolytic artefact of dehydroisoandrosterone sulphate, and only occurs when urines are hydrolysed under neutral conditions (Lieberman, Mond, and Smyles, 1954).

It is well known that destruction and transformation of ketosteroids may occur during hydrolysis of the conjugates in hot acid solution, especially of dehydroisoandrosterone in which the $3 \beta(\mathrm{OH})$ group is substituted by chlorine or removed to form the diene, 3:5 androstadien-17-one. These hydrolytic artefacts occur in Fraction I, which is usually roughly equal to Fraction III, and in such chromatograms it is necessary to add these two fractions to obtain an approximation of the true $\beta$-ketosteroid value (Table IV). 